\title{
The art of self-beliefs.
}

\section{A Boudonian approach to social identity}

\author{
Fernando Aguiar \\ IESA-CSIC \\ faguiar@iesa.csic.es
}

Received: 19-03-2014

Accepted: 05-06-2014

\begin{abstract}
In spite of recognizing that the concept of beliefs is a basic ingredient of our identity, Raymond Boudon neither developed a belief-based theory of social identity nor paid special attention to the concept. This article will attempt to shed some light on why Boudon excluded identity from his work and inquire if his social theory can be used to address the issue. We suggest that it is possible to build the concept of identity on Boudon's model of action by defining identity as a special kind of belief - a belief about oneself or self-belief.
\end{abstract} Keywords: cognitive rationality; identity beliefs; homo economicus; homo sociologicus; Raymond Boudon.

Resumen. El arte de las autocreencias. Una aproximación boudoniana a la identidad social

A pesar de que Raymond Boudon reconoce que el concepto de creencia es uno de los ingredientes básicos de nuestra identidad, no desarrolló una teoría de la identidad social basada en las creencias ni prestó especial atención al concepto. En este artículo se intentará arrojar luz sobre los motivos por los que Boudon excluyó de su obra la identidad y se analizará si su teoría social se puede emplear para abordar el asunto. Lo que proponemos es que cabe la posibilidad de construir el concepto de identidad apoyándose en el modelo boudoniano de acción, lo que lleva a definir la identidad como una clase especial de creencia: una creencia sobre uno mismo o autocreencia.

Palabras clave: racionalidad cognitiva; creencias de identidad; homo economicus; homo sociologicus; Raymond Boudon. 


\author{
Summary \\ 1. Introduction \\ 2. Homo sociologicus, homo economicus \\ and identity \\ 3. Boudon's theory of social action \\ and the identity oblivion \\ 4. The possibility of a Boudonian \\ approach to social identity \\ 5. Boudon's anti-Humean theory \\ of action \\ 6. Conclusion \\ Bibliographic references
}

\title{
1. Introduction
}

The fertile work of Raymond Boudon spans the most diverse fields of sociology, from his empirical work on unequal opportunities to his theoretical work on the nature of social action. Following in the footsteps of the great classics such as Tocqueville, Marx, Weber, and Pareto - whose works he knew well - there are few sociological issues that Boudon did not address. There is, however, one exception: social identity. It is not that Boudon did not dedicate any of his work to this topic (there was no need for him to do so), but the term hardly appears in his most important works, which is surprising given its importance. For example, the concept of social identity is not dealt with in the analytical indexes of Theories of Social Change (1986), The Analysis of Ideology (1989), The Art of Self-Persuasion (1994) or The Origin of Values (2000) nor can it be found in most of his articles or in the Dictionnaire critique de la sociologie (1982, 2004, written with Françoise Bourricaud).

Not surprisingly, the issue of social identity is also absent in those works that analyze Boudon's contribution. For instance, in her interesting book, Cynthia Lins Hamlin (2002) does not discuss social identity and in the monumental tribute to Boudon edited by Mohamed Cherkaoui and Peter Hamilton (2009), comprising four volumes, only the chapter by Max Haller explores identity, but in a way that has nothing to do with Boudon's work.

Why did the author of The Analysis of Ideology ignore the issue of social identity despite it being central to sociology? What are the reasons for this decision? This article will attempt to shed some light on why Boudon excluded this key concept from his work and inquire if his theoretical approach can be used to address the issue of social identity that he chose to overlook. To this end, the following section will present some of the criticisms of the often vague and confusing concept of identity, as well as two attempts to overcome these criticisms - a sociological approach influenced by interactionist theory and the rational-choice reductionist project. After presenting Boudon's model of social action in the third section, we will try to understand why he did not address the question of identity. In the fourth section we make a proposal for what could be a Boudonian approach to identity. Falling back on our previous work (Aguiar and de Francisco, 2009) we defend that social identity is a set of positive and normative collective beliefs individuals have about themselves; beliefs that give 
social actors reasons for action. As we are going to see, Boudon's social theory and his anti-Humean theory of action fit well in with this belief-based conception of identity (section five). Conclusions are drawn in the final section.

\section{Homo sociologicus, homo economicus and identity}

The literature on social identity is simply overwhelming. The topic of identity, which became "one of the unifying frameworks of the intellectual debate of the nineties" (Jenkins, 1996: 7), has not decreased in importance in the twentyfirst century. However, when delving further into the literature we soon come up against numerous conceptual obstacles. To begin with, we must tackle the enormous amount of adjectives that accompany the noun identity (personal, sexual, racial, ethnic, political, civic, cultural, social, collective, national, religious, local, and so on) (Somers and Gibson, 1994: 66). To the best of my knowledge, no other relevant category in the social sciences, perhaps with the exception of role, is bedecked with such a long cloak of adjectives. Take, for example, the habitual use of categories such as class, status, power, capital, group, action, structure, authority or organization. It seems as if the semantic content of the concept of identity were plunged into obscurity and light can only be shed upon it by resorting to other concepts that serve to define it. Starting from this conceptual inflation, the main criticisms regarding the concept of social identity have been grouped into three categories (Brubaker and Cooper, 2000; Davis, 2006).

\section{a) Conceptual ambiguity}

The meanings of "identity" abound in the sociological, political science and psychological literature. Identity can be understand as people's concept of who they are and how they relate to others; biological aspects grounded in a socially constructed meaning of identity (race, gender); identification with national, cultural or linguistic symbols; role-specific understanding and expectations about self; cognitive schemata by which the individual knows the world; the prescriptive representation of political actors; expressivist behavior or noninstrumental modes of action; or the unstable, multiple and fragmented contemporary self, among others (Giddens, 1991). These myriad definitions pose reasonable doubts as to the usefulness of a concept which is at best vague and encompasses multiple definitions, as well as the causal tie between identity and action (MacInnes, 2004).

\section{b) Categories of practice vs. categories of analysis}

It is often difficult to distinguish if identity refers to the way in which people understand or see themselves in everyday life and in their social, political or economic practice, or if identity refers to an analytical concept embedded in a theory of social action. In other words, identity is not distinguished so much as a category of social practice but rather as a category of analysis (Brubaker and Cooper, 2000: 4). 


\section{c) Social identity does not exhaust personal identity}

When identity is defined as a process of social identification, people are considered to be "embodiments of group prototypes rather than as independent individuals" (Davis, 2006: 6). Personal identity thus vanishes in a hypersocialized conception of the individual. But given the notably widespread consensus that people have multiple identities, it is necessary to appeal to individual or personal identity as a reference for the individual who reflexively chooses what he or she wants to be. That is, if social identity involves fitting individual action to a social category that others attribute to us, personal identity would imply fitting the action to the image that one has or wishes to have about oneself. This is a complex process full of ambiguities and incoherencies that can affect identification with others. For this reason, "without some account of the 'bearer' of a set of social identities, saying that an individual identifies with others is largely an empty claim" (Davis, 2006: 9).

The criticisms of hypersocialized versions of identity have, however, been a catalyst for the development of new theories that try to strike a balance between elements that are the product of social context, those that are a product of interaction, and those that are irreducibly personal. In what follows, we will see two prominent examples in this regard, which will be useful later to approach identity in Boudonian terms.

\subsection{Homo sociologicus and identity}

Luis is a 35-year-old black male, the father of one child, tall, married, a member of a football club, Spanish, a trade unionist, a high school teacher, of Guinean descent, an anti-bullfighting activist, a fervent defender of gender equality and outgoing. Some of Luis' traits are biological, others are social; some are a product of chance, others of need; some are the result of deliberate decisions, others of the consequences (foreseen or not) of those decisions; and yet others are culturally determined. Surely all these traits do not encompass all of what Luis is; but we can say that Luis is, at least, all that. In reality, any subset of traits that we might select would accurately identify Luis to a greater or lesser degree, although none would encompass all his properties. It should go without saying that what interests us here are Luis' socially shared traits; those that shape his social identity.

However, Luis' identity would not permit us to affirm, for example, that he takes part in a pro human rights movement because he is black, or that he participates in a demonstration on May $1^{\text {st }}$ because he is a trade unionist, or that he defends his homeland because he is Spanish. In fact, there are many black people who do not participate in anti-racism movements, many Spaniards who are not willing to defend their homeland, and many trade unionists that go for a picnic on the $1^{\text {st }}$ of May. Hence, it appears that something more must be added to these identifying traits in order to explain Luis' social action, either as an individual or as a member of a group. 
Indeed, this "something more" is composed of three elements whose purpose is to integrate individual and social aspects in a general conception of identity. What we call "self" is a complex mixture of individual and social elements in which we must first distinguish the self-concept: "In general, the self-concept is the set of meanings we hold for ourselves when we look at ourselves" (Stets and Burke, 2003: 130). This set of meanings is constructed by observing ourselves, through inferences about ourselves, the behavior of others towards us, and our desires. Part of what we call "self", then, emerges through a process of evaluative self-reflection (Mead's "looking-glass self”).

The self-concept, however, is not a passive aspect of people, but is instead subject to self-assessment, the second component of "self". Self-assessment has received much attention in recent years (Cast and Burke, 2002). It is understood as self-esteem in a twofold manner as being competent and able (efficacybased self-esteem) and feeling valued and accepted (worth-based self-esteem).

Finally, social identity is the third element of a "self" understood as a synthesis of individual and social aspects. Identity is the organization of that "self" into "multiple parts (identities), each of which is tied to aspects of the social structures" (Stets and Burke, 2003: 132). What does it mean, for example, to be a parent, a trade unionist, a colleague or friend? From the perspective of agency, it is, firstly, the ability of people to give content (meaning) to these roles of parent, trade unionist, colleague or friend. Social roles are not cast in molds, but provide a margin of freedom: social agents can interpret and implement them in different ways. This, in turn, implies the possibility of creating new roles, as in the case, for example, of what is known as "new masculinities", that is, new ways of interpreting the social role of "man" - men's engagement in active fatherhood, masculinities embodied in managerial practices, and so on (Anderson, 2009).

From a structural perspective, adopting roles means we are governed by certain norms and rules, since ability to recreate social roles does not mean that we should act with our children as a trade unionist or with union members as a parent. Thus, the answer to the question of what roles mean (both in their agential and structural aspects) is the "content of identities" (Stets and Burke, 2003).

The expression of the social "self" through social roles that acquire their meaning through interaction and contribute to the development of a reflective self-concept is therefore far from the old idea of a rigid, hypersocialized homo sociologicus. Our individual Luis, for example, holds egalitarian beliefs about what it means to be a father or a husband, and these beliefs are shared with other parents and husbands, but not all of them. To put it another way, Luis plays the role of father/husband on egalitarian terms. Moreover, very complex elements have intervened in his self-esteem, such as his profession or the fact that his parents were Guinean immigrants. These elements mean that Luis is embedded in a system of roles whose meanings provide him an identity that far from being rigid can be interpreted in strategic and normative terms, among others. 
So, is social identity from this perspective a category of analysis or a category of practice? It is both because identities are not only attributed to individuals in the form of labels, but the categorization is related to the meaning the roles have for the individuals themselves (Turner, 1999).

\subsection{Homo economicus and identity}

The most orthodox rational choice has always ignored the question of social identity. For the classical model of rational choice theory, the goal of individuals is to maximize their welfare or utility given their beliefs and preferences. Beliefs are rational if they are based on all the available information. In turn, preferences are rational when they are logically consistent, that is, if they do not contradict each other, if one thing and its opposite are not preferred at the same time, if they are transitive, complete, etc. Under these conditions, it can be assumed that individuals always act as if they would try to maximize their interest, and that is the only reason needed to explain social action.

According to this approach, theories of social identity are said to needlessly multiply the reasons for action, that is, they are not parsimonious. The best thing therefore is to adopt a reductionist strategy concerning social identity. In its more orthodox versions of rational choice, that strategy has been radical because it assumes that speaking about identity is equivalent to speaking about the specific interests of a person or a group of people who attempt to maximize their utility. It doesn't matter that Luis is a Spaniard of Guinean origin and a trade unionist; what essentially matters are the preferences he reveals through the action and not a supposedly objective identity (Hardin, 1995: 7).

A second, strategy, which is less orthodox and radical, also holds that identity is reducible to interest, but not only instrumental interest, as there are also expressive interests. According to Morris Fiorina, for example, "expressive factors probably dominate instrumental factors as an explanation of turnout" (1976: 410). What is at issue, then, is to consider the expression of identity - what one is - as another argument of the utility function (Akerlof and Kranton, 2010). For instance, we do not vote for one or another party just to maximize our self-interest, but to express our political identity, as the cost of voting is greater than the benefit to be gained. To continue with our example, Luis does not vote for the Socialist Party because it will benefit him, but because he is a socialist. Hence, we must include among Luis' preferences the fact that what he wishes to express is his identity. Only then can the fact that he votes be explained (Schuessler, 2000).

Without the conceptual richness of the interactionist-based sociological perspective, rational choice has managed to include identity in its research program (Calvert, 2000), and although it may have become less parsimonious, it is now more realistic. Both currents, that of sociological tradition and that of economic tradition, have left behind the old evils of the structural-functionalist concept of identity (conceptual ambiguity, the quasi-objective conception of 
identity, hypersocialization, and so on). Let us now see if we are capable of understanding why Boudon did not partake in this revival.

\section{Boudon's theory of social action and the identity oblivion}

Boudon's theory of action may provide us with some clues to understand, firstly, why the French sociologist almost entirely ignored social identity in his work, although it has remained one of the key issues in the social sciences, as we have just seen. Furthermore, this will allow us to ask which conception of identity follows from his theory. Although the answer to these questions is speculative, since Boudon himself never raised these issues systematically, it is worth inquiring into them as they shed light on his theoretical position as well as the concept of identity.

As is known, for Boudon a social phenomenon $\mathrm{M}$ is the aggregate product of a set of actions $m$ taking place in the situation S (Boudon, 1989):

$$
\mathrm{M}=\mathrm{M}\{\mathrm{m}[\mathrm{S}(\mathrm{P})]\}
$$

Let us look at each of the elements of this equation, which we will subsequently tie in with social identity. The phenomenon $\mathrm{M}$ we are interested in is the result of actions -explained in terms of attitudes and beliefs - of a set of individuals $m$. Following in the Weberian tradition, Boudon denied the explanatory value of collective concepts, which he instead understood as the result of individual interaction. For example, we cannot say that the Protestant ethic - to once again use this classic example - is responsible for the rise of capitalism without explaining the actions, attitudes and beliefs (interaction in short) of Protestants. In other words, the phenomenon M is a function of or a variable that depends on the set of individuals that are responsible for the phenomenon, that is, $\mathrm{M}=\mathrm{M}\left(\mathrm{m}_{\mathrm{i}}, \mathrm{m}_{\mathrm{j}}\right)$, where the subscripts denote the categories to which these individuals belong. To avoid being accused of inconsistent social atomism, Boudon ignored individuals "who are responsible for $\mathrm{M}$ in their concrete individuality, but we shall classify them in general categories" (Boudon, 1989: 243); categories that may have to do with the sex, gender or social roles of individuals. That is important to understand that the type of methodological individualism Boudon defended is close to what has been termed structural individualism (Hedström and Bearman, 2009: Chapter 1; Boudon and Fillieule, 2004). Indeed, the interaction of a set of individuals $m$ gives rise to the phenomenon $\mathrm{M}$ in a given situation $S$ that allows these individuals to be categorized. On the one hand, explaining or understanding (verstehen) a social phenomenon implies understanding the logic of the situation $S$, which is determined by a structural factor $\mathrm{P}$-the labor market, for instance, or a set of social norms. On the other hand, however, it is important to examine individual attitudes and beliefs as understood by the social actors themselves involved in the structural situation $S(P)$. 
In this way, Boudon avoided what in his opinion were two of the evils of sociology: structuralist hyperfunctionalism and the rationalism of the homo economicus (Boudon, 2006; Lins Hamlin 2002: 12). In the first case, the social actor disappears under the weight of omnipresent and omnipotent objective structures that leave no room for explaining action in terms of intentions. In the second case, the social structure loses its importance to the sovereign action of rational utility-maximizing individuals. In contrast to the rationalism of rational choice, Boudon defended a Simonian model of subjective rationality (cognitive rationality) (Boudon, 1994; Boudon and Viale, 2000) in which people are not assumed to act as if they were rational and selfish, but that they have and give good, satisficing subjective reasons for behaving the way they do (Boudon, 1994, 2001, 2006).

This brief summary of Boudon's model will help us understand the feasible reasons why the French author ignored the concept of identity and how we can rescue it using his model. First, Boudon explicitly rejected identity as an essentialist theoretical concept that is a product of a hypersocialized conception of social actors. Thus conceived, people would have rigid identities that would determine their social behavior, which in turn would prevent them from interpreting their action on their own terms, that is, sticking to their own reasons. Identity would therefore be a structural concept that corsets action completely. Consider, for example, the concept of role. The role identity as a parent or high school teacher of our character, Luis, does not explain his action in a corseted way. Rather, as Boudon pointed out, individuals interact within systems of roles that do not override their intentionality, because they retain their ability to make decisions (Boudon, 1981). The beliefs and preferences of individuals are influenced by the role they play (the logic of the situation), but they do not define closed and absolute identities.

Let us think about cultural identity. Luis is a Spaniard of Guinean origin. What is his supposed cultural identity? What values have more weight when defining his social "self", those that his parents gave him or those of the country of his birth? The fact that Luis is Spanish does not mean that he has a set of values that cannot be judged, evaluated, compared and even rejected without Luis ceasing to be who he is. Cultural identity does not "lock" Luis into a set of incommensurable community values:

"Les notions indéfiniment déclinées aujourd'hui d'«identité culturelle» ou de "cultural embeddedness», qui invitent à voir les sociétés comme communautés ou des réseaux de "communautés» assises sur des systèmes de valeurs incommensurables, tendent à écarter par principe toute possibilité d'appréciation par l'observateur extérieur des pratiques ou des institutions en vigueur ici ou là. Pourtant, nous sentons bien que nous avons un droit à en juger. De façon générale, l'interprétation "postmoderniste» des valeurs apparaît comme en contradiction avec une multitude de faits facilement observables". (Boudon, 2000: 2). 
The essentialism of postmodern cultural identity prevents the outside observer from understanding why individuals act, which leads to relativism and violates the neo-Weberian postulate of explanation as understanding: the individual who does not belong to a culture or social category, it is said, cannot understand and therefore cannot explain the social action of members of that culture or category.

Thus, rather than the closed and incommensurable identity of the hypersocialized homo sociologicus (functionalist or postmodern), Boudon is closer to the reductionist strategy of orthodox rational choice, which is perhaps one of the reasons why he ignored the concept of identity. However, Boudon's reductionism was very different from that of rational choice. We have seen that the most orthodox rational choice rejects the explanatory utility of the concept of identity and reduces it to individual interests. Boudon, however, would be unable to accept this rationalist reductionism. He could not accept that identity is one more argument in utility functions. This would turn all individuals into irrational seekers of the best expression of their "best" self, just as an employer would try to maximize her profit or a party would try to maximize its number of votes. Arguably, then, Boudon's reductionism has nothing to do with rational choice.

The fact that Boudon did not pay as much attention to identity as to other key issues of sociology therefore has to do, on the one hand, with his outright rejection of functionalism and structuralism and their postmodern heirs. On the other hand, he could not be convinced of reducing the concept as rational choice theory does because it meant not rejecting the rationalist model of the utility-maximizing homo economicus. This gives us good reason to think that maybe for him the concept was useless.

However, we think it is not useless. In fact, what we think is that Boudon did not pay attention to the identity revival because his criticism focused on the orthodox versions of functionalism/postmodernism and rational choice, as we have just seen. Had he been interested in those sociological and economic identity theories that tried to overcome orthodox approaches, he might have developed his own theory. Unfortunately, he did not do that in spite of remaining alert to the evolution of sociological theory - but not regarding identity.

In the next section, then, we are going to tentatively see if his formula could permit us to find a way of interpreting identity in Boudonian terms.

\section{The possibility of a Boudonian approach to social identity}

Social identity can be the dependent variable to be explained or the independent variable which helps to explain other phenomena. In the first case, when the social phenomenon to be explained is identity, I (identity) would be equal to $\mathrm{M}$ :

$$
\mathrm{I}=\mathrm{M}=\mathrm{M}\{\mathrm{m}[\mathrm{S}(\mathrm{P})]\}
$$


Or what is the same,

$$
\mathrm{I}=\mathrm{I}\{\mathrm{m}[\mathrm{S}(\mathrm{P})]\}
$$

Social identity is explained through the actions $m$ of a set of individuals in a situation S: the social action of individuals is what explains their collective identity. This would be the case, for example, of rites of passage, where a series of actions must be performed in order to be admitted to the group to which we want to belong. Here the intentionality of the action is unquestionable: people seek an identity because they want that identity. This version of Boudon's formula has to do, then, with the agential aspect of identity, that is, the aspect in which individuals make or create their own role (identity role).

Let us consider again the case of Luis. Since we are not interested in his concrete individuality but the degree to which he belongs to a general category, we must explain (understand) his actions, which together with the actions of other individuals, shape his social identity. As a trade unionist and school teacher, Luis has a set of positive beliefs about his profession. Luis believes, for example, that teachers earn a low salary, work long hours, lack the means to improve the quality of education and that their profession is not valued highly by society. These beliefs may be true or false, but Luis has good reason to take them into account given the information available to him, the opinion of his peers, his assessment of the professional career of his friends who are not teachers, etc.

In addition to positive beliefs, Luis has normative beliefs about what is just and what is unjust, what is right and what is wrong in the world of work, what is fair and what is not. Positive and normative beliefs, which are not the product of a simple cost-benefit analysis, are of a "trans-subjective" nature (Boudon, 2001: 123), as Luis believes that his reasons are well grounded and he can therefore share them with others. This allows us to say that Luis does $\mathrm{X}$ (go on strike, for example) because he believes that $\mathrm{Y}$ is true, fair, good, and so on (Boudon, 1994: 255).

What then would be the identity, the "I" in the above formula? In the reductionist program we have ascribed to Boudon, beliefs are sufficient to explain social action and identity would therefore be a redundant concept. However, we are not forcing Boudon's model if we add, on an expressivist base, that social action is understood insofar as it reveals or expresses the positive and normative beliefs of social actors, both about the world and themselves. ${ }^{1}$ When Luis

1. Boudon's use of "belief" is not always clear, but we think it is implicitly close to that of the analytical philosophy of mind: "Analytic philosophers of mind generally use the term 'belief to refer to the attitude we have, roughly, whenever we take something to be the case or regard it as true. To believe something, in this sense, needn't involve actively reflecting on it [...] Nor does the term "belief", in standard philosophical usage, imply any uncertainty or any extended reflection about the matter in question (as it sometimes does in ordinary English usage). Many of the things we believe, in the relevant sense, are quite mundane" (Schwitzgebel, 2014). On the contrary, normative beliefs cannot be true or false. But both are mental states (Elster, 2007: Ch. 7). 
performs action $\mathrm{X}$, he is expressing what he $i$, he is expressing his social identity: a trade unionist and teacher in our example. Harboring the positive belief that situation X is true ("school teachers are paid little") and unfair ("it's not fair that some school teachers are paid so little") and acting in accordance with those beliefs involves developing a positive belief about oneself as a fair person: I (think that I) am a fair person. The notion then that identity is a set of positive and normative beliefs about ourselves that give us good reasons to act can be supported in Boudon's model. The set of actions $\left(\mathrm{m}_{\mathrm{i}}, \mathrm{m}_{\mathrm{j}}\right)$, based on the positive and normative beliefs $\mathrm{X}, \mathrm{Y}$, and $\mathrm{Z}$, give rise to a collective identity $\mathrm{I}$.

This interpretation of Boudon's formula in terms of social identity, which he did not do but can be deduced from his model of social action without forcing it, allows us to address the other side of the matter, namely, those situations in which identity is the independent variable:

$$
\mathrm{M}=\mathrm{M}\{\mathrm{i}[\mathrm{S}(\mathrm{P})]\}
$$

Here it is not a question of explaining how identity is formed from a set of actions $m$, but understanding how certain aggregate phenomena $\mathrm{M}$ occur (go on strike, make war, vote, make family decisions, etc.) from the expression of identity $i$, which is given. Once identity is understood as a set of positive and normative beliefs, the most varied of social phenomena can be explained. Thus, for example, the joint action of Catholics who, with good subjective reasons, believe in God and believe that they should go to church and go because they think they are the type of people who fulfill their religious duties make the Church stronger.

This tentative Boudonian approach to identity seems to lack the defects that the French author attributed to hypersocialized theories or rational choice. It is neither a deterministic approach that establishes direct causal links between identity and action without attending to the microfoundations of identity, nor an empty maximizing exercise. On the contrary, social identity is a set of collective beliefs (positive and normative) individuals have about themselves; beliefs that give social actors reasons for action (Aguiar and de Francisco, 2009).

\section{Boudon's anti-Humean theory of action}

We have seen that the identity of the homo sociologicus is complex. It is shaped by the social roles of a "self" that conceives itself through its own observation and that of others, and well as its desires, beliefs and self-assessment. The most recent theories of identity do not rely on the classical homo sociologicus of functionalism or the orthodox homo economicus of rational choice. What is the point then of reducing this complex identity to mere beliefs? Beliefs are a part of the self-concept, but not the only one; desires should also be a prominent part of identity. However, does not a theory that focuses on beliefs impoverish the concept of identity? 
As Cynthia Lins Hamlin points out, Boudon's theory of cognitive rationality is not only a theory of action, but "a theory of beliefs (both positive and normative) which draws on the strong reasons that agents have for doing what they do or believing what they believe" (Lins Hamlin, 2002: 2-3). Or to put it another way, beliefs provide reasons for action and that is what helps explain the action from the perspective of the subjects themselves. Beliefs that are positive (which may be true or false) and normative always respond to situations of interaction: "they are instituted at the meeting point of a personal history, personal projects and the situation of the actor" (Boudon and Bourricaud, 1986: 46). That meeting point could be seen as the social identity of an individual, and if the identity can explain action, we have to appeal to the beliefs that explain (permit understanding) that action. This does not mean that affective and volitional aspects are not important to understanding action; Boudon often stresses the importance of emotions and desires or preferences (Boudon, 2001). The implication is that even if they are sufficient, they are not necessary, unlike beliefs, which are necessary and often sufficient. Boudon's theory is thus clearly anti-Humean: beliefs have their own motivational force and the action does not always need the desire-belief pair to be explained. If I have a beer in a pub, my action to pay for it is not explained by my desire to pay, but by the normative belief that I must pay (Searle, 2001). But the fact that the action does not always need the desire-belief pair to be explained does not mean that it never needs it. What is important here to understand Boudon is that these desires are often the dependent variable of an explanation in which beliefs are independent variables: "beliefs can play the role of independent variables, that is to say, they appear as cause rather than effect, not only in individual development but in social change" (Boudon and Bourricaud, 1986: 46). Beliefs are, then, the cause of action and when the action relates to what a person believes he is or believes he should be these beliefs about one's self or identity beliefs explain the action (I vote socialist because $I$ am a socialist, for example). ${ }^{2}$ On the other hand, when identity beliefs are the dependent variable we have to explain their genesis based on "what we sometimes call, in rather a vague term, social structures" (Boudon and Bourricaud, 1986: 44). In any case, far from impoverishing the concept of identity, Boudon's action theory allows us to reconstruct it on grounds that go beyond the Humean model inasmuch as he gives motivational force to beliefs.

It is doubtful, however, that Boudon would support the interpretation of identity we have presented here. Given Boudon's rejection of all forms of psychologism, he might well consider that the concept of identity involves an unnecessary psychologization of social beliefs. However, it is a path that is worth pursuing to at least overcome two of the problems of his theory of action. The first is the absence of a clear definition of "belief" throughout his

2. Having the desire to vote socialist is explained by the fact of being socialist, not the other way round - I am not socialist because I desire to vote socialist. Being socialist is to share with other persons a set of beliefs about the world and about ourselves. 
work. Although here we have implicitly assumed that beliefs are mental states (see footnote 2), this "mentalism" seems to be foreign to the French author's work, although he sometimes succumbs to it. A Boudonian theory of identity beliefs would make it necessary to define the very concept of belief in more detail.

The second problem is that of the "danger of adhocness" (Manzo, 2012: 39), which affects Boudon's version of good, subjective reasons for action. Indeed, one can always resort to a subjective reason to understand social action (workers have good reason to accept exploitation, the members of tribe $\mathrm{X}$ have good reason to believe in magic, etc.), meaning that his theory runs the risk of being uninformative: there will always be ad hoc reasons to explain any action. However, the expression of identity can be one of the "human invariants" that allow defining the scope of subjective reasons for action. As Gianluca Manzo argues with regard to the work of Boudon, "the link among social belonging, social identity and actor's beliefs...can help in building reason-based explanations that lead to fine-grained predictions ex-ante facto" (Manzo, 2012: 45). ${ }^{3}$ Identity gives us good reasons to act based mainly on positive and normative beliefs about ourselves. This also gives us good reason to think that perhaps Boudon would have accepted a Boudonian approach to identity.

\section{Conclusion}

In this paper we have tried to show that it is possible to draw a belief-based definition of social identity from Boudon's theory of social action. We think this is an interesting speculative task to perform because the French sociologist did not address the issue. He did not give us many clues to understand the reason why he rejected one of the key sociological concepts. However, in a first speculative exercise it can be established that Boudon was not interested in the identity question due to the ambiguity of a concept either hypersocialized by orthodox functionalists and postmodernists or reduced to preference maximization by the orthodox rational choice theory. Rejecting both theoretical trends entailed rejecting identity as an analytically useful concept. However, why did Boudon not pay attention to the new developments coming from interactionists and heterodox rational choice theorists, among others? We can only conjecture that it may have had to do with the logic of Boudon's situation: in France, the cradle of postmodern functionalism, Boudon felt the need to incessantly quarrel with postmodern thinkers. In fact, the only quotation on identity we have found is a criticism of postmodernism.

The second speculative exercise has consisted in posing the following question: Does Boudon's social action formula permit us to address the identity issue? Of course it does. At the same time it helps us to understand some interesting features of his work. First, we have seen that Boudon gives beliefs causal power: Beliefs are causes, not only effects, of social action. Inasmuch as beliefs

3. Manzo, however, does not accept a belief-based definition of social identity (Manzo, 2012). 
have motivational force - give us reasons for action - we do not always need a desire to understand individual and social actions. In breaking the Humean belief-desire pair that way we can defend that Boudon's theory is clearly antiHumean. Thus, it can be stated that a belief-based conception of identity fits in with his theory of action.

Of course these two speculative exercises are not free from serious problems. On the one hand, there are hermeneutic problems, that is, problems of interpreting Boudon correctly. Taking into account, for instance, that his belief definition is far from clear, it can be contested that we are right in saying the French sociologist is an anti-Humean thinker that gives beliefs motivational force. On the other hand, there are theoretical problems. If we put aside interpretation matters, the very proposal of understanding identity as a set of beliefs about oneself can be still questioned. However, tentative works are not useless if they open new research paths.

\section{Bibliographic references}

Aguiar, Fernando; DE Francisco, Andrés (2009). "Rational choice, social identity and beliefs about one self”. Philosophy of the Social Sciences, 39 (4), 547-571. http://dx.doi.org/10.1177/0048393109333631

Akerlof, George; Kranton, Rachel (2010). Identity economics: How our identities shape our work, wages, and well-being. Princeton: Princeton University Press.

Anderson, Eric (2009). Inclusive masculinity: The changing nature of masculinities. London: Routledge.

Boudon, Raymond (1981). La lógica de lo social. Introducción al análisis sociológico. Madrid: Rialp.

- (1989). The analysis of ideology. Chicago: The University of Chicago Press.

- (1990). "Subjective rationality and the explanation of social behavior". Rationality and Society, 2 (2), 224-228.

- (1994). The art of self-persuasion. Cambridge: Polity Press.

- (2000). "Pluralité culturelle et relativisme". Comprendre, 1, 311-339.

- (2001). The origin of values. Sociology and philosophy of beliefs. London: Transaction Publishers.

- (2006). "Homo Sociologicus: Neither a rational nor an irrational idiot". Papers, 80, 149-169.

Boudon, Raymond; Bourricaud, Francoise. (1986). A critical dictionary of sociology. Chicago: Chicago University Press.

Boudon, Raymond; Viale, Riccardo (2000). "Reasons, cognition and society". Mind and Society, 1, 45-56.

Boudon, Raymond; Fillieule, Renaud (2004). Le méthodes en sociologie. Paris: PUF.

Brubaker, Rogers; Cooper, Frederick (2000). "Beyond identity". Theory and Society, 29, $1-47$.

http://dx.doi.org/10.1023/A:1007068714468

Calvert, Richard (2000). "Rationality, identity and expression". In: Ira KatzNELson and Helen Milner (eds). Political Science: The State of the Discipline. New York: Norton. 
Cast, Alice; Burke, Peter (2002). "A theory of self-esteem”. Social Forces 80, 10411068.

http://dx.doi.org/10.1353/sof.2002.0003

DAvis, John (2006). "Social identity strategies in recent economics". Journal of Economic Methodology, 13, 371-390. http://dx.doi.org/10.1080/13501780600908168

Elster, Jon (2007). Explaining Social Behavior: More Nuts and Bolts for the Social Sciences. Cambridge: Cambridge University Press. http://dx.doi.org/10.1017/CBO9780511806421

Fiorina, Morris (1976). "The voting decision: Instrumental and expressive aspects". Journal of Politics, 38, 390-413. http://dx.doi.org/10.2307/2129541

Giddens, Anthony (1991). Modernity and self-identity: Self and society in the late modern age. Cambridge: Polity Press.

Haller, Max (2009). "Language and identity in the age of globalization". In: Cherkaoui, Mohamed and Hamilton, Peter (eds). Raymond Boudon, a life in sociology. Essays in Honour of Raymond Boudon. Oxford: The Bardwell Press.

Hardin, Russell (1995). One for All. Princeton: Princeton University Press.

Hedström, Peter; Bearman, Peter (2009). "What is analytical sociology all about? An introductory essay”. In: Hedström, Peter and Bearman, Peter (eds). The Oxford handbook of analytical sociology. Oxford: Oxford University Press.

Jenkins, Richard (1996). Social Identity. London: Routledge.

Lins Hamlin, Cynthia (2002). Beyond relativism: Raymond Boudon, cognitive rationality and critical realism. London: Routlege.

MacInnes, John (2004). "The sociology of identity: Social science or social comment?”. British Journal of Sociology, 55, 531-543. http://dx.doi.org/10.1111/j.1468-4446.2004.00036.x

Manzo, Gianluca. (2012). "Reason-based explanations and analytical sociology". European Journal of Social Sciences 50 (2), 35-66.

SeArle, John (2001). "Rationality and action". In: Branquinho, João (ed). The foundations of cognitive science. Oxford: Oxford University Press.

Schuessler, Alexander (2000). "Expressive voting". Rationality and Society, 12, 87-119.

http://dx.doi.org/10.1177/104346300012001005

Schwitzgebel, Eric (2014). "Belief”. The Stanford Encyclopedia of Philosophy (Spring 2014 Edition). Edward N. Zalta (ed.).

http://plato.stanford.edu/archives/spr2014/entries/belief. Retrieved 3 June 2014.

Somers, Margaret; Gibson, Gloria (1994). "Reclaiming the epistemological 'Other': Narrative and the Social Constitution of Identity". In: Calhoun, Craig (ed.). Social Theory and the Politics of Identity. Oxford: Blackwell.

Stest, Jan E.; Burke, Peter J. (2003). "A sociological approach to self and identity". In: LeAry, Mark R. and TANGney, June (eds.). Handbook of self and identity. New York: The Guilford Press.

Turner, J. C. (1999). "Some current issues in research on social identity and self-categorization theories”. In: Ellemers, Naomi; Spears, Russell and Doosje, Bertjan (eds). Social identity: Context, commitment, content. Oxford: Blackwell. 